\title{
The Assessment of Judicial Independence Following the CJEU Ruling in C-216/18 LM
}

\author{
Stanisław Biernat and Paweł Filipek
}

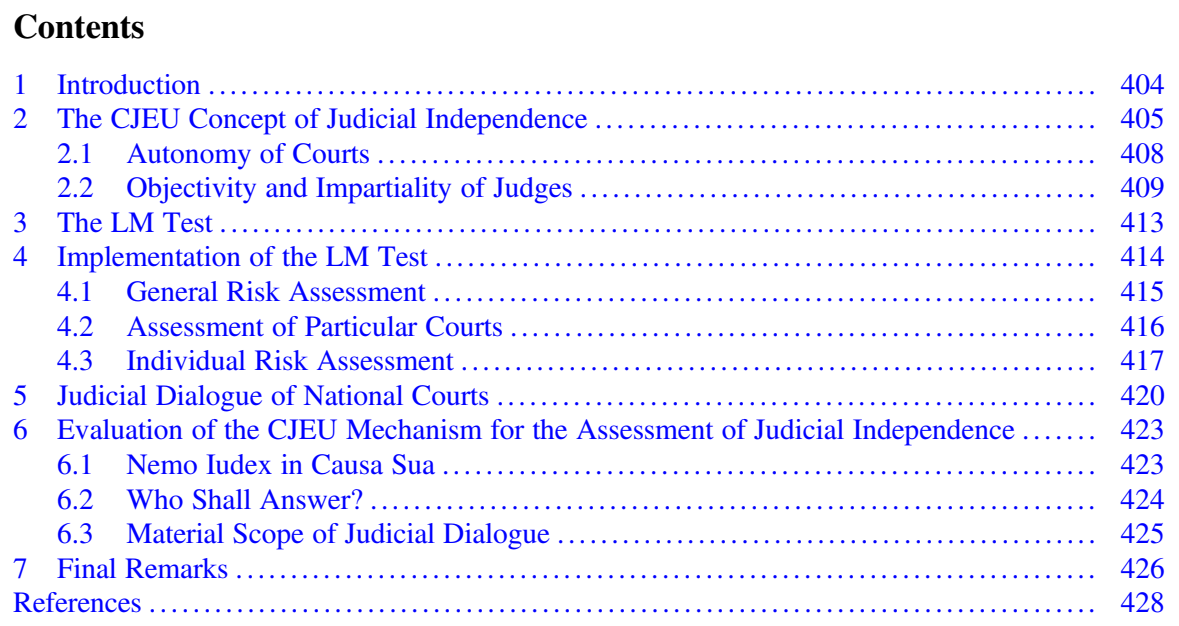

\begin{abstract}
In the LM ruling, the Court of Justice developed the Aranyosi and Căldăraru test and indicated it as the one to be applied for the assessment of judicial independence and fair trial guarantees in the context of executing European Arrest Warrants. Although serious threats to the rule of law and judicial independence in some EU countries, like Poland, have been documented over recent years, no warrant has so far been definitely rejected as a consequence of the application of the $L M$ test, although there are cases in which the execution of warrants to Poland has been suspended. This naturally raises questions as to whether the mechanism proposed by the Court responds to the need of protecting the right to a fair trial and
\end{abstract}

\author{
S. Biernat $(\bowtie)$ \\ Jagiellonian University, Krakow, Poland \\ e-mail: stanislaw.biernat@uj.edu.pl \\ P. Filipek \\ University of Economics, Krakow, Poland
}

(C) The Author(s) 2021

A. von Bogdandy et al. (eds.), Defending Checks and Balances in EU Member

States, Beiträge zum ausländischen öffentlichen Recht und Völkerrecht 298,

https://doi.org/10.1007/978-3-662-62317-6_16 
safeguarding judicial independence. In this contribution we evaluate the mechanism devised by the Court, taking into account the available judicial practice after the $L M$ ruling. We point out that the almost automatic transfer of a mechanism proposed to evaluate the functioning of a prison system to that evaluating a fair trial and judicial independence has not been fully successful. The mechanism proposed by the Court reveals a number of problematic issues and proves to be insufficient and not entirely adequate to assess judicial independence and guarantees of a fair trial.

\section{Introduction}

Immediately after its publication, the judgment in Case C-216/18 $L M^{1}$ generated different reactions in Poland and abroad. ${ }^{2}$ Some commentators treated the judgment as a general vote of no confidence in the Polish judiciary and especially with regard to the changes made into it in the recent years. Others, including the Minister of Justice, found it to be a defeat of the Irish court which referred the case to the CJEU, as the latter did not share all the suggestions made by the referring court. The $L M$ case and the Court's judgment have been used as an argument in the current political debate. Because of the CJEU approach to certain significant issues, the judgment received equivocal interpretation, and its full consequences may become apparent only after a certain period of time and in the light of the post- $L M$ judicial practice of domestic courts.

The wish of some political actors for the Court of Justice to provide an explicit negative assessment of the rule of law in Poland did not come true. Such anticipations did not take account of the specific nature of the preliminary ruling procedure. The $L M$ judgment essentially maintained the standard division of roles between the CJEU and national courts. CJEU is to provide interpretation of EU law and give guidance to national courts. ${ }^{3}$ In turn, the national courts are to pass judgments in the domestic proceedings, yet having regard to this guidance. A separate question is, whether the result of this division of roles and the actual instructions issued in the $L M$ ruling can prove satisfactory in practice.

There is no doubt that the judgment is of a certain significance for the development of EU case law and the arguments set forth therein may potentially apply to various situations and proceedings. Because of that, some of the findings of the

\footnotetext{
${ }^{1} \mathrm{CJEU}$, Case C-216/18 PPU, Minister for Justice and Equality (Deficiencies in the system of justice), ECLI:EU:C:2018:586. The case is regularly referred to, in an abridged form, as the 'LM case'. The text builds on previous publications of the authors: Biernat (2018), Filipek (2018), Filipek (2019).

${ }^{2}$ See. i.a. the debate on Verfassungsblog: https://verfassungsblog.de/category/debates/after-celmer/ (Accessed 20 Jul 2019); Bogdanowicz and Taborowski (2018a), Grabowska-Moroz (2018a).

${ }^{3}$ See e.g. CJEU, Recommendations to national courts and tribunals in relation to the initiation of preliminary ruling proceedings (2019) C380/1, especially paras. 1, 5 and 11.
} 
CJEU were formulated in a more general manner, especially in respect of two major perspectives. First, the Court developed and supplemented the arguments invoked in the Case C-64/16 Associação Sindical dos Juizes Portugueses, ${ }^{4}$ concerning the notion and meaning of independence of national courts in the light of EU law. Secondly, the Court continued to set the limits of mutual trust and exceptions to the principle of mutual recognition of court decisions on account of the denial of fundamental rights in the context of executing a European Arrest Warrant. ${ }^{5}$ In doing so, the CJEU developed its earlier ruling in cases C-404/15 and C-659/15 PPU Aranyosi and Căldăraru on a number of issues. ${ }^{6}$ In this chapter we focus on some points of the $L M$ judgment from the first of the aforementioned perspectives taking account of the domestic judicial practice that has followed the CJEU ruling.

\section{The CJEU Concept of Judicial Independence}

A central notion in the $L M$ ruling is the independence of the judiciary. In the Court's view, the requirement of judicial independence forms part of the essence of the fundamental right to a fair trial. The right is of cardinal importance as a guarantee that all the rights which individuals derive from EU law will be protected and that the values common to Member States set out in Article $2 \mathrm{TEU}$, in particular the value of the rule of law, will be safeguarded. (para. 48). It is clear, the independence of the judiciary forms the essence of a fair trial and the right to effective judicial protection. At the same time, it lies in the very heart of the rule of law. ${ }^{7}$ Without judicial independence, the state legal system can only provide an illusion of the rule of law.

In recent years, however, in some EU Member States, we have been witnessing the undermining of the role of independent judiciary. Without it, the protection of all human rights is impaired, including the right to a fair trial. Yet, respect for the right to effective judicial protection is a necessary and inalienable prerequisite for the protection of all other fundamental rights. ${ }^{8}$ From the perspective of threats to the protection of judicial independence and thus to the rule of law and to fundamental rights, the $L M$ ruling marks a further step towards building and consolidating the defense of the EU legal order and Union values against states that seem to be

\footnotetext{
${ }^{4}$ CJEU, Case C-64/16 Associação Sindical dos Juízes Portugueses v. Tribunal de Contas, ECLI: EU:C:2018:117.

${ }^{5}$ In this regard, see i.a. Grzelak (2018), especially pp. 51-54, 57-63; Xanthopoulou (2018), Lenaerts (2017), Anagnostaras (2016).

${ }^{6} \mathrm{CJEU}$, Case C-404/15 and C-659/15 PPU, Pál Aranyosi and Robert Căldăraru v. Generalstaatsanwaltschaft Bremen, ECLI: EU:C:2016:198.

${ }^{7}$ 'The very existence of effective judicial review designed to ensure compliance with EU law is of the essence of the rule of law.', CJEU, Associação Sindical, supra note 4, para. 36.

${ }^{8}$ See e.g. Górski (2016), p. 37; Safjan (2018), pp. 559-560; Safjan (2019), pp. 5 and 10.
} 
abandoning them and threaten the entire European project. ${ }^{9}$ A new, specific point which was made by the CJEU is the following: if the national court executing the European Arrest Warrant finds that there are substantial grounds for believing that the person in respect of whom that warrant has been issued, will-following his surrender to the issuing judicial authority-run a real risk of breach of his fundamental right to an independent tribunal and, therefore, of the essence of his fundamental right to a fair trial, it may ultimately refrain to give effect to the warrant (para. 73).

In developing the understanding of judicial independence, the CJEU relied on the concept worked out in its previous case law and voiced i.a. in the Associação Sindical judgment. In the $L M$ ruling, the Court broadened its view on the elements that make up and substantiate judicial independence (para. 63-67). This is one of the most important aspects of the judgment whose relevance goes beyond the specific case brought by the Irish High Court.

The notion of 'court' was elaborated in CJEU jurisprudence in the context of the preliminary reference procedure. ${ }^{10}$ The CJEU enjoys the power to verify whether a request for a ruling comes from an authorised body, i.e. a 'court or tribunal'. It is empowered to do so both on party's request or of its own motion, when deciding the admissibility of the preliminary ruling request. The Treaty does not determine which body is to be considered a court, yet the Court of Justice has consistently pointed to a number of criteria which it takes into account when assessing if a body is in fact a 'court or tribunal'. The traditional Court's formula reads as follows:

the factors to be taken into account in assessing whether a body is a 'court or tribunal' include, inter alia, whether the body is established by law, whether it is permanent, whether its jurisdiction is compulsory, whether its procedure is inter partes, whether it applies rules of law and whether it is independent. ${ }^{11}$

It is thus not the formal denomination as a 'court' that is decisive for the actual classification of the body admitted under Article 267 TFEU. What matters most of all is whether it carries out the function of adjudicating; if it acts as a judicial body. This entails a number of elements. The court proceedings are initiated by action of a party that wants to have a dispute settled. Bringing the case to the court results in the lis pendens, and precludes autonomous action in another ordinary court. ${ }^{12}$ In most

\footnotetext{
9 'The collapse of the rule of law in any member state is tantamount to the rupture of a legal space in the entire European Union.', Safjan (2019), p. 7.

${ }^{10}$ See e.g. Lenaerts et al. (2014), p. 52 et seq.; Dashwood et al. (2011), pp. 214-216; Schütze (2018), pp. 389-391; Schwarze (2012), pp. 2234-2235. On the legitimacy of a uniform understanding of the term 'court' both in Article 267 TFEU and Article 47 Charter, see i.a.: Pech (2014), p. 1251; Górski (2016), p. 39; Bogdanowicz and Taborowski (2018a), p. 9. For an in-depth discussion of the differences in the concept of a 'court' under both articles see Grzeszczak and Krajewski (2014), pp. 5-11.

${ }^{11} \mathrm{CJEU}$, Associação Sindical, supra note 4, para. 38; almost identical with the original formula CJEU, Case C-54/96 Dorsch Consult Ingenieurgesellschaft mbH, ECLI:EU:C:1997:413, para. 23.

${ }^{12}$ CJEU, Case C-503/15 Ramón Margarit Panicello v. Pilar Hernández Martínez, ECLI:EU: C:2017:126, para. 34 .
} 
cases, judicial proceedings are by nature adversarial, and are characterised by opposing positions of the parties. The proceedings eventually lead to a binding ruling. ${ }^{13}$ Furthermore, the court cannot refrain from taking a position on the case; it is entitled and, at the same time, called upon to consider and decide the case.${ }^{14}$ The final ruling of the court has the effect of res judicata. ${ }^{15}$

It is clear that the independence of the body belongs to the constitutive elements of a 'court' and is intrinsic to the very basic idea of adjudication. This is why it forms an essential requirement of the right to an effective remedy provided for by Article 19 TEU and Article 47 EU Charter of Fundamental Rights. As such it must be guaranteed both at the EU level, within the CJEU, but equally by the Member States at the national level with respect to domestic courts. ${ }^{16}$ The Court of Justice in the Associação Sindical case proclaimed a general obligation of EU members to guarantee and respect independence of their judiciaries. ${ }^{17}$ Domestic courts once they are qualified as a 'court or tribunal' under EU law and are empowered to rule on EU legal issues, have become 'European courts' ('Union courts') whose independence is now protected by the Union, its institutions and the Union's legal system. ${ }^{18}$

The guarantees of judicial independence are intended to protect both the courts and judges as well as those whose cases they handle. Firstly, they create an environment for the judge that enables him $^{19}$ to carry out the judicial function being confident about professional and personal safety. The judge must not fear that another public authority will not appreciate the court's decision and that he may suffer some negative consequences for that reason. Secondly, the guarantees of judicial independence provide the parties with a sense of confidence and certitude that the court will keep equal distance from the parties. ${ }^{20}$ The facts of the case and the

\footnotetext{
${ }^{13}$ See also Lenaerts et al. (2014), p. 53.

${ }^{14}$ 'It is called upon to give judgment in proceedings intended to lead to a decision of a judicial nature', CJEU, Panicello, supra note 12, para. 28.

${ }^{15}$ Id., at 34; see also Górski (2016), pp. 39-40; Wachowiec (2019), pp. 568-571; for a critical review of these criteria see Grzeszczak and Krajewski (2014), pp. 7-9.

${ }^{16}$ See CJEU, Associação Sindical, supra note 4, para 42.

${ }^{17}$ See Pech and Platon (2018), p. 1828.

${ }^{18}$ See also Lenaerts (2018), p. 8.

${ }^{19}$ We use the pronoun 'he' throughout the text, and not the longer formula 'he or she', only for the reasons of readability.

20 'Guarantees of independence and impartiality require rules (...) in order to dismiss any reasonable doubt in the minds of individuals as to the imperviousness of that body to external factors and its neutrality with respect to the interests before it', CJEU, Case C-506/04 Graham J. Wilson v. Ordre des avocats du barreau de Luxembourg, ECLI:EU:C:2006:587, para. 53; see also recent CJEU rulings related to Polish courts: CJEU, Case C-619/18, Commission v. Poland (Independence of the Supreme Court), ECLI: EU:C:2019:531, paras. 74, 111; CJEU, Case C-92/18 Commission v. Poland (Independence of ordinary courts), ECLI:EU:C:2019:924, paras. 111, 124; CJEU, Case C-585/18, C-624/18 and C-625/18 A.K. and Others v. National Council of Judiciary and Supreme Court (Independence of the Disciplinary Chamber of the Supreme Court), ECLI:EU: C:2019:982, paras. 128, 153.
} 
applicable law are of sole relevance to the court, and it shall not take into account other considerations. When, in the end, the court delivers a judgment, it is indeed the very law that speaks. ${ }^{21}$

\subsection{Autonomy of Courts}

Unquestionably, there is a need to assess the independence of the national judiciary on the basis of a common EU standard. In its case law, the Court of Justice identified external (objective) and internal (subjective) aspects of independence, that to a large extent remain in line with the set of criteria indicated by the European Court of Human Rights. $^{22}$ They consist in guaranteeing, on the one hand-the autonomy of the court and, on the other-the objectivity and impartiality of the judge. In a similar way, judicial independence is understood in the jurisprudence of the Polish Constitutional Tribunal. ${ }^{23}$

Judicial independence sets the limits of political influence on the judiciary. ${ }^{24}$ When considering a case, the court must remain autonomous. It must be free from outside influence, is protected against external intervention or pressure liable to jeopardise the independent judgment of its members as regards proceedings before them'. ${ }^{25}$ It is presumed that 'the court exercises its functions wholly autonomously, without being subject to any hierarchical constraint or subordinated to any other body and without taking orders or instructions from any source whatsoever, ${ }^{26}$

These preconditions are ensured by the principle of separation of powers, organizational and functional autonomy of courts which are entrusted with the task of

\footnotetext{
${ }^{21}$ Only in exceptional cases accepted the Court of Justice as a 'court or tribunal' a body that was not fully independent. It occurred in some cases of administrative bodies which were also acting in a judicial capacity. In such situations the Court required the separation of functions between the departments responsible for administrative tasks and the departments vested with judicial functions. The judicial activities by the latter should be carried out without receiving any instruction from the former. See e.g. CJEU, Case C-110/98 Gabalfrisa SL and Others v. Agencia Estatal de Administración Tributaria (AEAT), ECLI:EU:C:2000:145, para. 39.

${ }^{22}$ For an in-depth analysis of ECHR case law on judicial independence, see i.a. Hofmański and Wróbel (2010), pp. 314-325; Lawson (2018), Sillen (2019).

${ }^{23}$ 'Legislative and executive powers cannot exercise judicial power or interfere in areas in which judges are independent', Constitutional Tribunal (Judgment), Case Kp 1/15, Law on the Organization of Ordinary Courts, OTK ZU 147/9A/2015, para. III.2.4; 'Independence comprises many elements, namely: (1) impartiality vis-à-vis the parties to the proceedings; (2) independence from non-judicial bodies (institutions); (3) autonomy of the judge in relation to the authorities and other judicial organs; (4) independence from political factors; (5) internal independence of the judge. The independence of a judge is not only the right of a judge but also his constitutional duty, as is the constitutional duty of the legislature and judicial administration bodies to protect the independence of a judge', id., para. III.2.5; see also Constitutional Tribunal (Judgment), Case K 47/15 Novelization of the Act on the Constitutional Tribunal, OTK ZU 31/A/2018, para. III.6.1.7.

${ }^{24}$ See Lenaerts (2018), p. 5.

${ }^{25} \mathrm{CJEU}$, Wilson, supra note 20, para. 51; CJEU, LM, supra note 1, para. 63.

${ }^{26} \mathrm{CEU}$, Panicello, supra note 12, para. 37; CJEU, LM, supra note 1, para. 63.
} 
administering justice. Other public bodies should be deprived of instruments by which they could exert pressure on courts to comply with their instructions or expectations.

In Commission v. Hungary the Court of Justice addressed the issue of political influence. It held that the mere risk that political influence could be exercised is enough to hinder the body in the independent performance of its tasks. ${ }^{27}$ It continued by indicating a particular example of such influence: a threat of a premature termination of the body's term of office. This could lead to 'prior compliance' that would be incompatible with the requirement of independence. ${ }^{28}$ In this case, the Court of Justice was not referring to a national court, but to a supervisory authority for the protection of personal data, which in accordance with Directive $95 / 46^{29}$ was required to exercise its functions 'with complete independence'. There is no good reason why the protection of the independence of judicial bodies should deserve anything less. ${ }^{30}$

The current lack of effective separation of powers and the undermining of judicial independence, especially in the absence of guarantees of constitutional review, jeopardises the protection of human rights and disrupts the balance of powers. The consequences of the above deficiencies may be severe and far-reaching, beginning with a de facto change of a state's political and legal system. As the conduct of the parliamentary majority over the last few years in Poland demonstrates, the Constitution may be ignored or interpreted in a hostile manner. ${ }^{31}$

\subsection{Objectivity and Impartiality of Judges}

The second aspect of judicial independence embraces the impartiality and objectivity of the members of the court. As the CJEU pointed out, it 'seeks to ensure a level playing field for the parties to the proceedings and their respective interests with regard to the subject-matter of those proceedings. (...) [it] requires (...) the absence of any interest in the outcome of the proceedings apart from the strict application of the rule of law. ${ }^{32}$

In its previous case law the Court recognised a number of personal and institutional guarantees of independence and impartiality, in particular with respect to: court composition; appointment of judges; length of their service; grounds for

\footnotetext{
${ }^{27}$ CJEU, Case C-288/12 Commission v. Hungary, ECLI:EU:C:2014:237, para. 53.

${ }^{28}$ Id., para. 54.

${ }^{29}$ Directive (EC) $95 / 46$ on the protection of individuals with regard to the processing of personal data and on the free movement of such data (1995) OJ L281/31.

${ }^{30}$ Likewise, Bogdanowicz and Taborowski (2018a), pp. 9-10.

${ }^{31}$ See also i.a. Łętowska (2018), p. 614 et seq.; Wyrzykowski (2017), p. 831 et seq.; Sadurski (2018, 2019).

${ }^{32}$ CJEU, Wilson, supra note 20, para. 52.
} 
abstention, rejection and dismissal; protection against removal from office ${ }^{33}$ (in particular, the dismissals of members of that body should be determined by express legislative provisions) ${ }^{34}$ or remuneration of judges which should correspond to their function. ${ }^{35}$

A new accent in the $L M$ judgment that expands the Court's perception of guarantees of judicial independence is the incorporation of some qualitative features of disciplinary proceedings against judges. It can be presumed that this is related to the Polish context. The Court pointed out that the system of disciplinary measures should be regulated in such a way that it cannot be used for political control of the content of court rulings. In this context, the Court stressed the need for a normative definition of: the conduct constituting disciplinary offences; the disciplinary penalties; the defendant's right to defence; and the right to appeal against a disciplinary ruling. This point of the $L M$ judgment can be seen as a response to the reasoned proposal made by the European Commission under Article 7(1) TEU. ${ }^{36}$ It is worth noting that, in addition to the legislative dimension, the actual application of the disciplinary regime to individual judges should equally be taken into account. Even if the disciplinary system met the criteria provided in the $L M$ ruling at a normative level, its application in individual cases should be also taken into consideration. It is apparent that the situations, the manner and the context in which disciplinary proceedings against judges are instituted, or even the very incidents where judges are threatened with disciplinary responsibility, may intentionally lead to an oppressive effect and interfere with judicial independence. It is expected that the standards of disciplinary regime for judges will be further developed in the course of the infringement action brought in October 2019 by the European Commission against Poland under Article 258 TFEU. The Commission made an evaluation of disciplinary investigations in Poland and concluded that they may be triggered by the content of judicial decisions. This clearly undermines judicial independence and puts judges at risk of political control. The Commission claimed breach of Article 19 (1) TEUeffective judicial protection, and Article 267 TFEU - the right of a domestic court to refer questions for a preliminary ruling, because of the possibility of the initiation of a disciplinary proceeding if the court exercises that right. ${ }^{37}$

A further contribution to the development of the European concept of judicial independence was made by the CJEU in two recent infringement cases on the independence of the Polish Supreme Court $^{38}$ and the independence of ordinary courts $^{39}$ initiated by the European Commission on the basis of Art. 258 TFEU. In

\footnotetext{
${ }^{33}$ Id., paras. 51 and 53 .

${ }^{34}$ CJEU (order), Case C-109/07 Jonathan Pilato v. Jean-Claude Bourgault, ECLI:EU:C:2008:274, para. 24.

${ }^{35} \mathrm{CJEU}$, Associação Sindical, supra note 4, para. 45.

${ }^{36}$ Taborowski (2019), p. 397.

${ }^{37}$ CJEU, Case C-791/19 Commission v. Poland, ECLI:EU:C:2020:277.

${ }^{38} \mathrm{CJEU}$, Independence of the Supreme Court, supra note 20.

${ }^{39} \mathrm{CJEU}$, Independence of ordinary courts, supra note 20.
} 
both of them the Court of Justice found that Poland failed to fulfil its obligations to ensure effective judicial protection. In the course of time, there will be more and more CJEU rulings concerning the effects of changes in the Polish judiciary, as a number of Polish courts have referred questions to the Court for a preliminary ruling. The Court has recently responded to first of these questions (the case A.K. and Others). ${ }^{40}$

In both infringements rulings the CJEU underlined the protection of the judges against removal from office, and analysed the mechanism to extend judge's mandate after reaching the retirement age. The Court of Justice emphasised that the principle of irremovability requires that judges may remain in post provided that they have not reached the obligatory retirement age or until the expiry of their mandate, where that mandate is for a fixed term. ${ }^{41}$ Though the CJEU admitted that the protection against the removal is not absolute, it nonetheless stressed that the interference with the principle can only be justified on 'legitimate and compelling grounds' and must satisfy the proportionality test. ${ }^{42}$ Whether these substantive and formal conditions are met may now clearly be subject to European scrutiny.

The Court examined in detail the mechanism for extending the active service of a judge. The mechanism is acceptable and it is the exclusive competence of the Member State to decide whether to make use of it in the domestic system. However, EU members are not free to impose arbitrary conditions and rules of such prolongations; their competence is limited by the requirement to ensure that the procedure does not undermine judicial independence. Indeed, neither the rule of law nor the principle of judicial independence prohibits the use of such a procedure, even if the non-judicial (e.g. executive) bodies are involved in its application. Yet, it is prohibited to shape the procedure in such a way that it may interfere with the independence of a judge by tempting him or her, even potentially, to give in to external intervention or pressure. ${ }^{43} \mathrm{~A}$ judge who considers himself to be fit to continue in active service may be inclined to rule in conformity with the expectations of those who will examine the request and/or decide on the prolongation. Recognising the deficiencies of the procedures to extend the mandate of the Supreme Court judges by the President of the Republic and the judicial activity of ordinary courts judges by the Minister of Justice, the CJEU pointed to the discretionary nature of the President's and Ministerial powers, the lack of objective and verifiable criteria for their decisions, no obligation to state reasons for the decision and the lack of a judicial remedy against a possible refusal. ${ }^{44}$

\footnotetext{
${ }^{40} \mathrm{CJEU}$, A.K. and Others, supra note 20.

${ }^{41}$ Id., para. 76; CJEU, Independence of ordinary courts, supra note 20, para. 113. ${ }^{42} \mathrm{Id}$.

${ }^{43}$ See CJEU, Independence of the Supreme Court, supra note 20, paras. 110-112; CJEU, Independence of ordinary courts, supra note 20, paras. 118-120.

${ }^{44} \mathrm{CJEU}$, Independence of the Supreme Court, supra note 20, para. 114; CJEU, Independence of ordinary courts, supra note 20 , para. 122 . It was a paradox that a judge could have appealed from a preparatory, non-binding opinion of the National Council of the Judiciary which was to advise the President on whether to prolong the judge's mandate; while he could not have appealed against a final negative decision.
} 
Another aspect of the Independence of the Supreme Court ruling which deserves special emphasis is that the examination whether judicial independence is preserved in a Member State, may also include checking what were the true aims of judicial reforms. ${ }^{45}$ This is the case when serious doubts arise as to whether the aims declared by the government (e.g. standardizing the retirement age; improving the age balance of judges) justify the implementation of the specific measures, e.g. lowering the retirement age of judges, or granting a discretionary power to the political body to extend the active service of a judge. After all, a premature dismissal of judges appears not to be a very subtle means by the government to fill the 'vacated' judicial posts with their own appointees. ${ }^{46}$ The examination of the actual aims focuses on the justification and the proportionality of the measures adopted. It covers not only the grounds for their application and the degree of discretion conferred on state bodies, but equally, other modalities of their implementation, e.g. compulsory nature, discriminatory effect, or retro-active application, as well as the results they may lead to (i.e. the removal of judges from the office).

In the most recent judgment $A . K$. and Others, delivered in the preliminary ruling procedure, the CJEU developed a method for assessing the independence of a judicial body. ${ }^{47}$ Referring to the functioning of the newly established Disciplinary Chamber of the Supreme Court, but also to the National Council of the Judiciary, which participated in its staffing, the CJEU indicated the criteria for assessing, whether the body preserves its independence, ergo, whether it is in fact a court in the meaning of EU law. ${ }^{48}$ In keeping with the terms of the judicial dialogue based on Article 267 TFEU, the CJEU left it up to the national court to carry out the assessment and draw conclusions. ${ }^{49}$ The consequences of the CJEU ruling and the subsequent domestic judgments will be of major importance for both national and European administration of justice.

\footnotetext{
${ }^{45} \mathrm{CJEU}$, Independence of the Supreme Court, supra note 20 paras. 82 et seq. Twenty years ago, in Köllensperger and Atzwanger, the CJEU declared a request for a preliminary ruling from the Tiroler Landesvergabeamt admissible despite the fact that the provisions on the removal of its members were vague; the Court applied a general presumption that public authorities act in compliance with the national constitution and the rule of law; Case C-103/97 Josef Köllensperger GmbH \& Co. KG and Atzwanger AG v. Gemeindeverband Bezirkskrankenhaus Schwaz, ECLI:EU: C:1999:52, para. 21 and 24.

${ }^{46}$ See also Kuijer (2018), pp. 532-533.

${ }^{47} \mathrm{CJEU}$, A.K. and Others, supra note 20.

${ }^{48}$ These criteria include the circumstances in which the body was set up, its characteristics and nature, the manner in which it operates and the public perception of its work; see CJEU, A.K. and Others, supra note 20, paras. 143-153.

${ }^{49}$ The domestic court made such an assessment in a judgment of 5 December 2019. The threeperson panel of the Polish Supreme Court (Chamber of Labour and Social Security) ruled that the National Council of the Judiciary is not an impartial and independent body, and the Disciplinary Chamber of the Supreme Court is not a court within the meaning of EU law (case ref. no. III PO $7 / 18)$.
} 


\section{The LM Test}

The general views of the CJEU on judicial independence set out above have been concretised in the $L M$ case with regard to the EAW mechanism. The concretisation concerns the extent of obligations incumbent on judicial authorities which decide to execute the EAW at the request of judicial authorities of Member States with regard to which allegations of breach of the rule of law have been made, including interference with judicial independence. These obligations then consist in carrying out an independence test and ensuring that the fundamental right of the requested person to a fair trial is not at risk.

In the $L M$ ruling the Court of Justice confirmed, in a different context, the essential application of the Aranyosi and Căldăraru mechanism to assess the risk of a breach of a fundamental right. ${ }^{50}$ Ergo, the test applies also when the doubts are raised with respect to judicial independence and the fairness of a court trial.

In the operative part of the $L M$ judgment, the Court reiterated the two tests introduced in Aranyosi and Căldăraru: the general test and the individual one (paras. 68, 79, and the conclusion). It is a prima facie conclusion when reading literally the wording of the judgment itself. This is also how most of the literature commented on this ruling. Yet, a more profound analysis brings us to the point that we may distinguish indeed, not a two- but a three-step test, which more accurately reflects the process of verifying the conditions for the execution of the EAW. The CJEU adapted the original test, by introducing an intermediate stage between a general and the individual risk assessment (para. 74). That stage comprises the assessment of judicial independence of the very courts which are competent to hear the individual case of the requested person. The Court thus indicated that the fair trial guarantees should be considered at three levels: general, intermediate and individual, accordingly making a distinction of: (1) a general risk assessment; (2) the assessment of particular courts competent to deal with proceedings concerning the person covered by the EAW; and (3) the individual risk assessment.

(1) The general test of Aranyosi and Căldăraru was left unchanged. It is used to determine whether there is a real risk that the fundamental right to a fair trial may be breached on account of systemic or generalised deficiencies concerning the judiciary, such as to compromise judicial independence in the Member State that issued the arrest warrant (para. 68).

(2) The next is the test of particular courts, i.e. the courts which have jurisdiction over the proceedings for which the individual person was requested by the warrant. At this stage, the executing court should determine to what extent systemic or generalised deficiencies in judicial independence (that were identified under the general test) may affect these courts (para. 74). The introduction of

\footnotetext{
${ }^{50}$ See also Taborowski (2019), p. 394 et seq.; Taborowski (2018), p. 73 et seq.; Bogdanowicz and Taborowski (2018b), Lewandowski (2019), p. 10; Frąckowiak-Adamska (2018b), p. 98 et seq.; Krajewski (2018), p. 796; Grabowska-Moroz (2018b), p. 21; Nita-Światłowska (2018), p. 8.
} 
the intermediate stage is justified by the subject-matter of the assessment which is different from the other tests and, consequently, by the nature of questions that the executing court needs to consider. Only if the existence of such an impact is confirmed, the judicial authority can take the final test.

(3) The third test in the CJEU mechanism is the individualised test in relations to the specific case and the individual person being prosecuted. It aims to answer the ultimate question, whether there is a real risk of a breach of the fundamental right to a fair trial of the person subject to the arrest warrant. In making this assessment, the executing court should take into account the specific concerns of the person prosecuted and his personal situation, the nature of the offence, the circumstances in which it was committed and the context in which the EAW was issued (para. 75).

The evolution of the two-step Aranyosi and Căldăraru test into the three-step LM test has already been explicitly reflected in national court decisions taking into account the $L M$ judgment. Indeed, the Irish High Court followed the three-stage pattern in its ruling to surrender the suspect. ${ }^{51}$ Then, the Supreme Court of Ireland which considered the appeal from the High Court's ruling applied the three-step approach as well and concluded that 'although there was clear evidence of breach of Poland's Charter and Treaty obligations (. . .) and further evidence leading the trial judge to conclude that a breach of the principle of independence did operate at the level of the courts involved, the available evidence did not, on its own, satisfy the third stage of the test set out by the C.J.E.U. (...)'.52

The consecutive steps of the $L M$ test require further analysis and more detailed commentary, which will be made in the following section.

\section{Implementation of the LM Test}

Judicial independence is an undisputed legal standard of the European Union. Member States have the primary responsibility for ensuring it. ${ }^{53}$ The verification of whether Member States fulfil this responsibility can be centralised, i.e. carried out by the EU institutions in the framework of political procedures (e.g. the protection of the rule of law, Art. 7 TEU) or judicial proceedings (e.g. an infringement action, Art. 258 TFEU).

Since the $L M$ ruling, it has become apparent that the courts in other Member States also have the right and the duty to play an active role in safeguarding the

\footnotetext{
${ }^{51}$ High Court (Judgment of 19 November 2018), The Minister for Justice and Equality v. Artur Celmer (No. 5), [2018] IEHC 639, paras. 92-98 and 117.

${ }^{52}$ Supreme Court (Judgment of 12 November 2019, The Minister for Justice and Equality v. Artur Celmer, S:AP:IE:2018:000181, para. 85.

${ }^{53}$ See CJEU, LM, supra note 1, paras. 52-57; CJEU, Independence of the Supreme Court, supra note 20 , para. 71 .
} 
proper standard of judicial independence in the European legal area. The competence of domestic courts in this area is deemed to be a 'safety valve ${ }^{54}$ and a means to protect the EU legal order against the destructive influence of action of certain Member States which are not compliant with the rule of law. ${ }^{55}$ The Court of Justice has therefore recognised that this responsibility is also decentralised and lies with all 'Union' courts, including national judiciaries.

\subsection{General Risk Assessment}

Concerns can be raised in relation to each of the steps of the above test. The mechanism established by the Court of Justice is complex and multilevel. It also appears to be difficult to implement in practice and the degree of difficulty increases with passing to the subsequent levels. From a methodological perspective, the easiest stage to carry out seems the first level: the general test. It may require a considerable amount of work on the part of the executing authority, as it consists in gathering and assessing the information on the general situation in the judiciary of the issuing state.

In this context, the question may be asked: what is the significance of the reasoned proposal of the European Commission opening the proceedings pursuant to Article 7 (1) TEU $?^{56}$ Would a similar document, if prepared by the European Parliament, e.g. a resolution on Hungary, ${ }^{57}$ or filed by Member States, have a role to play? The Court held in the $L M$ ruling that the information provided by the Commission in the proposal is 'particularly relevant' for the purposes of the general risk assessment (para. 61). Thus, the national court is to take account of the information contained in the Commission document. ${ }^{58}$

Nonetheless, it is to be noted that such a document will not be issued in future in each case of suspicion of the risks discussed. After all, in the history of the Union to date, it has only happened once (or twice, if the EP resolution on Hungary is to be counted). In the specific situation in which the Irish High Court was to take the decision, there were no obstacles to relying on the findings and conclusions of the Commission. In particular, no obstacle stemmed from the fact that the Commission proposal was adopted under a different procedure of a political rather than judicial nature; or from the fact that the decision of the Council under Article 7 (1) TEU had

\footnotetext{
${ }^{54}$ Taborowski (2019), p. 49, 375 et seq.

${ }^{55}$ See Barcz (2019), pp. 4, 12-13.

${ }^{56}$ European Commission, Reasoned proposal in accordance with Article 7 (1) of the Treaty on European Union regarding the rule of law in Poland, 20 December 2017, COM(2017) 835 final.

${ }^{57}$ European Parliament, Resolution on a proposal calling on the Council to determine, pursuant to Article 7(1) of the Treaty on European Union, the existence of a clear risk of a serious breach by Hungary of the values on which the Union is founded, 12 Sep 2018, P8_TA(2018)0340.

${ }^{58}$ See also Taborowski (2019), p. 399.
} 
not been taken before the national court reached its decision on the execution of the warrant.

However, may the national court fully rely on the information presented in the Commission's proposal or perhaps it should verify or supplement it? The CJEU judgment is vague in this regard (cf. para. 61, 69, 73, 79). Yet, it seems justified that the national court may rely on the proposal of the Commission bearing in mind its detailed nature and extensive documentation. It should not, however, be confined to the Commission's document only. It should verify whether this document is up to date and, if necessary, gather further material.

The reference by the Court to the Commission's reasoned proposal should be seen as a recognition of the document as a source of information ensuring a high standard of reliability. Nonetheless, it is left to the executing authority to choose and evaluate the sources of information. The CJEU indicated the qualitative criteria of the information on which the executing authority should base its evaluation: the information should be objective, reliable, specific and properly updated (para. 61). In principle, any sources which provide information helpful for the general risk assessment can be used by the national court. The executing court should examine them, so that its determination is based on accurate, complete and exhaustive information that gives a true representation of the situation.

\subsection{Assessment of Particular Courts}

Further doubts arise in relation to the next levels of the assessment procedure, i.e. the determination whether there are serious and proven grounds to conclude, in the circumstances of the given case, that the prosecuted person will be exposed to the risk of a breach of the right to a fair trial as a result of being surrendered to the issuing state. The doubts concern both the procedural and the substantive aspects of the mechanism devised by the CJEU.

The executing judicial authority is required to assess whether the general or systemic deficiencies in judicial independence indeed affect the courts which have jurisdiction in criminal cases against the persons requested by the EAW. In the first place, it needs to identify the courts in the issuing state which have jurisdiction to rule on the matters in question. This will require to apply the rules of criminal procedure of that state, either by the executing court itself or with the assistance of other authorities, including the issuing court, e.g. through the judicial dialogue (Art. 15 (2) EAW Framework Decision). In principle, the courts' jurisdiction can be established before the person is transferred to the issuing state. In situations specified by the law in force, it may nevertheless be subject to change after the person's transfer. The risk of the potential change of jurisdiction after the surrender of the person prosecuted creates the danger that the assessment made by the executing authority will not be correct. It is equally difficult for the executing authority to predict later developments in the case. Assessment of the independence of the 
specific courts competent to carry out proceedings against the person wanted, is therefore only of limited usefulness to safeguard the fair trial guarantees to the individual person.

The example of the manner in which the Oberlandesgericht in Karlsruhe dealt with a EAW case (Ausl 301 AR 95/18), provide an interesting illustration of the difficulties that the executing courts may encounter when assessing the guarantee of the independence of judges by whom the requested persons would supposedly be tried after the transfer. Initially, the German court held a dialogue with the Polish court to clarify the doubts that had arisen and to gather additional information with regard to judicial independence in Poland. In doing so, it followed the formula indicated by the CJEU (see infra). The correspondence with the Polish counterpart did not allow to clarify all doubts of the German court. In the course of the dialogue, the Oberlandesgericht asked specifically for a binding assurance under international law that no disciplinary proceedings will be instituted against judges with regard to the content of their decisions taken during the trial of the requested person. ${ }^{59}$ After having received a reply that such an assurance is not possible, the court then decided to make the consent for the surrender of the requested Latvian citizen subject to the assurances that the German ambassador or a person authorised by him will be entitled to be present at the trial conducted with respect to that person and, in the event of a conviction, to visit him in custody. ${ }^{60}$ By proceeding in that way, the Oberlandesgericht apparently went beyond the formula outlined by the Court of Justice.

\subsection{Individual Risk Assessment}

The Court of Justice's test as proposed in the $L M$ ruling, raises the most serious concerns as regards the final test: the examination of the individual risk. At this stage, the executing judicial authority is to make a final determination as to whether the requested person's fundamental right to a fair trial is at risk. The executing judicial authority ought to take into consideration: the specific concerns expressed by the person prosecuted as well as his personal situation, e.g. the political pressure to prosecute or punish him; possible negative statements by state officials about the person wanted; his possible membership of political opposition, social or ethnic minority; or media activities critical of political power, etc. In addition, the judicial authority should take account of the nature of the offence, the circumstances in which it was committed as well as the context in which the arrest warrant was issued,

\footnotetext{
${ }^{59}$ Oberlandesgericht Karlsruhe (Decision of 31 October 2018), Ausl 301 AR 95/18, para. 33.

${ }^{60}$ Oberlandesgericht Karlsruhe (Decision of 7 January 2019), Ausl 301 AR 95/18, para. 70.
} 
e.g. the political nature of the act; or the fact that the act was committed in connection with the exercise of the freedom of expression or the freedom of assembly, etc. ${ }^{61}$

Taking the individual test means that the foreign national court has already carried out the two previous stages. It must have then established that judicial independence is endangered in the Member State which requested the surrender of the person, and it must have further recognised that this danger exists also in relation to the particular courts that are to try the person requested. At this stage, there should be therefore no doubt that the Member State whose judicial system is subject to such an examination does not respect the values of the Union, in particular the principle of the rule of law and its fundamental element: judicial independence. Some legal scholars suggested that refusal to execute EAWs should take place after general or systemic deficiencies in judicial independence in the given Member State had been identified. ${ }^{62}$ However, this was not enough for the CJEU to complete the test. This is where the Court of Justice came to the rescue of the principle of mutual trust and the mutual recognition of judicial decisions. By protecting the EAW cooperation mechanism by requiring all three levels of the $L M$ test to be carried out, the CJEU de facto accepted that judicial independence was threatened in the Member State which issued the warrant. This is perhaps the most controversial outcome of the LM ruling. ${ }^{63}$

The Court of Justice assumed that the actual realisation of the standard of judicial independence in a given Member State may vary. Moreover, this variation may occur at different levels, corresponding to the levels of the $L M$ test. The existence of systemic or generalised deficiencies in the judiciary (the general test) may affect national courts to a differing degree: some courts may be affected, while some others not (the intermediate test). Furthermore, the determination that these deficiencies do have an impact on a particular court still does not preclude, in the Court's view, that in such a court a certain person in a specific criminal proceedings may be tried in accordance with the European standard of judicial independence (the individual test). ${ }^{64}$ Therefore,

\footnotetext{
${ }^{61}$ CJEU, $L M$, supra note 1, para. 75. See also written observations in the $L M$ case of the European Commission of 30 April 2018, paras. 23-24; CJEU, Case C-216/18, LM, Opinion of Advocate General E. Tanchev, ECLI:EU:C:2018:517, para. 103.

${ }^{62}$ E.g. Bárd and van Ballegooij (2018a) Judicial Independence; von Bogdandy (2018), Krajewski (2018), p. 805; Pech and Wachowiec (2019).

${ }^{63}$ See also i.a. von Bogdandy (2018), Frąckowiak-Adamska (2018a), Scheppele (2018), Grabowska-Moroz (2019), p. 427; Pech and Wachowiec (2019). It is suggested that in addition to preserving the mutual recognition mechanism, the CJEU intended to distinguish its responsibility (to protect the right to a fair trial in individual cases, based on Art. 19 (1) TEU and Art. 47 Charter), from that of the Council and the European Council (to oversee the systemic compliance of domestic judicial systems with the rule of law, stemming from Art. 7 TEU); see CJEU, LM, supra note 1, paras. 70-72; CJEU (opinion), LM, supra note 63, paras. 40, 42 and 44; Frąckowiak-Adamska (2018a), Krajewski (2018), p. 797.

${ }^{64}$ The Court clearly followed the line suggested by the European Commission and supported by the Advocate General; see European Commission (Written observations of 30 April 2018), para. 19; CJEU (opinion), LM, supra note 63, para. 108. See also Bárd and van Ballegooij (2018b) The AG Opinion, para. 2.2; Taborowski (2019), pp. 400-401.
} 
the third stage of the $L M$ test is indeed decisive. It makes the test highly rigorous and extreme, to the point that it becomes rather challenging to justify a refusal to execute a European Arrest Warrant.

The Court will soon re-examine the methodology indicated in the LM ruling following two new preliminary references brought by the Amsterdam Court (C-354 and 412/20). The Court in Amsterdam has asked how to deal with Polish warrants, once it has concluded that the independence of every court in Poland is at risk due to systemic deficiencies caused by changes introduced in recent years, including the possibility of initiating disciplinary proceedings for the content of judicial decisions.

There is another crucial aspect of the $L M$ ruling that will definitely have far-reaching consequences for the EAW mechanism. It is the obligation of the executing court to request the issuing authority to provide additional information that it considers necessary for assessing whether there is a risk to a fair trial (the Q\&A mechanism). The CJEU stated so in both Aranyosi and Căldăraru (para. 95), and $L M$ (para. 76) cases. The Court of Justice applied the modal verb 'must' in the context of requesting additional information, which suggests that this horizontal judicial dialogue is of a compulsory nature and national courts cannot derogate from this duty. Such interpretation has been expressly accepted by some executing authorities. ${ }^{65}$ Indeed, especially the second and third stages of the procedure developed by the CJEU will generally require launching of a Q\&A mechanism. The detailed information that would be needed to carry out the assessment of particular courts as well as the specific case and individual situation of the suspect, usually, will not be fully known to the executing court. However, it should be left to the discretion of the executing authority to decide whether the information in its possession is sufficient for taking a decision about the execution of a EAW, or whether any supplementary information is needed.

The horizontal judicial dialogue is based on Article 15 (2) of the EAW Framework Decision ${ }^{66}$ and is intended to allow the collection of 'necessary supplementary information', in particular as regards the grounds for non-execution of the warrant, the guarantees to be provided for its execution or the warrant's content or form. The issuing judicial authority may provide the executing court with any objective material in relation to any changes concerning the conditions for protecting the guarantee of judicial independence in the issuing Member State, which may rule out the existence of that risk for the individual concerned (para. 77). The issuing body may as well seek assistance, if need be, from the central authority or one of the central authorities of the issuing Member State (para. 78). Yet, both the CJEU approach to the formula of judicial dialogue and a relatively short practice of its use reveal a number of issues concerning the way in which it is actually carried out.

\footnotetext{
${ }^{65}$ See e.g. Rechtbank Amsterdam (Decision of 16 April 2019), ECLI:NL:RBAMS:2019:2721, section 4.4.

${ }^{66}$ Council Framework Decision 2002/584/JHA on the European arrest warrant and the surrender procedures between Member States, OJ L190/1.
} 


\section{Judicial Dialogue of National Courts}

This part of the contribution presents the experience gained so far in the dialogue between the executing judicial authorities of different Member States and the issuing judicial authorities in Poland. It covers the dialogue not only of the particular courts which were competent in the case which led to the $L M$ judgment, but also of other courts which applied the mechanism prescribed by the Court of Justice in other EAW cases. Most of the documents were obtained via the access to public information mechanism; ${ }^{67}$ occasionally, some answers of Polish courts to the questions asked by the executing authorities were also made available on the respective courts' websites. The information obtained can be regarded as representative of other cases of judicial dialogue inspired by the $L M$ judgment. They follow a similar pattern and show fairly common deficiencies. It should be noted, however, that this mechanism is still at its debut and may be subject to further evolution.

Following the CJEU ruling in the $L M$ case, the Irish High Court complied with the requirements set out by the Court of Justice. It twice requested the supplementary information from Polish courts that issued the arrest warrants. In the end, the court in Dublin decided to execute all three warrants and ordered the surrender of the person wanted to Poland. ${ }^{68}$ The Irish court confirmed its earlier assessment of the existence of a general risk of breach of the right to a fair trial due to systemic or general deficiencies in judicial independence in Poland. ${ }^{69}$ It also concluded that these deficiencies will affect the courts before which the person wanted will be tried. ${ }^{70}$ Ergo, it did determine that two out of the three tests of the $L M$ ruling were met. Nonetheless, with respect to the last one: the final assessment of the existence of an individualised risk for the prosecuted person, the Court held that this risk was not proven. ${ }^{71}$ The prosecuted person filed an appeal from the High Court's judgment which was examined by the Supreme Court of Ireland. The Supreme Court shared the assessment of the lower instance and eventually ruled in November 2019 to dismiss the appeal. ${ }^{72}$

The dialogue carried out in the $L M$ case illustrated some problems of the Q\&A mechanism established by the CJEU, which will be addressed below. The analogous judicial dialogue initiated in other EAW cases, e.g. by the courts of Madrid,

\footnotetext{
${ }^{67}$ The courts were asked for information twice: in November 2018 and in June/July 2019. While in the first round only about half of the courts replied, in the second round the success rate of the requests increased to some $80 \%$. Perhaps this should be linked to the paper, which was the result of the first series of inquiries and was published in a legal periodical regularly consulted by judges; see Filipek (2019).

${ }^{68}$ Celmer No. 5, supra note 53, para. 123.

${ }^{69}$ Id., para. 93.

${ }^{70}$ Id., para. 97.

${ }^{71}$ Id., para. 117.

${ }^{72}$ Supreme Court, supra note 54, para. 88 .
} 
Amsterdam or Karlsruhe, also shows that the mechanism is deficient and the 'Union courts' are not fully capable to make use of it.

The questions posed by different courts varied greatly in terms of the content and the level of detail: from the most general questions from the Spanish court to inquisitive, detailed sets of questions from the Dutch and German courts. The most frequent questions concerned systemic, structural issues of the Polish judiciary, including the autonomy of courts in performing their tasks, the irremovability of judges, the composition of adjudicating panels, the available legal remedies, the dismissal of presidents and vice-presidents of courts, disciplinary proceedings, etc. ${ }^{73}$ Questions referring directly to particular courts that have jurisdiction to hear the case of the person wanted were less frequent. Questions of this kind were raised primarily by the courts of Amsterdam and Karlsruhe (including: indication of competent bodies, changes in court's staff, recent retirement or transfer of judges in the competent courts, allocation of cases, rules on case resolution, disciplinary proceedings, or measures to protect the right to an independent court). ${ }^{74}$ Some of the questions on particular courts were indeed of a general nature. In fact, there were only occasional questions related to the last stage of the $L M$ test: the personal situation and concerns of the person prosecuted, or the nature of the offence and the circumstances in which it was committed. The latter category included questions about statements made by the deputy minister of justice referring to the person prosecuted as a dangerous offender, which the Irish court interpreted as likely to undermine the presumption of innocence of the person prosecuted. ${ }^{75}$

The analysis of the responses of Polish courts indicates that they may assist the executing authority in taking a decision to surrender a person prosecuted only to a limited extent. Many replies consisted mainly in a brief presentation of general legal rules concerning the judiciary: provisions of the Constitution/statutes and the submission of some basic data requested by the foreign court. In fact, this kind of replies prevailed. Occasionally, they were supplemented with some superficial conclusions, e.g.: 'In Poland, legal norms exclude threats to the independence of judges ${ }^{, 76}$ Only a few answers of the courts (judges) were explicitly critical, and negatively assessed the existing situation and expressed doubts about the independence of judges. In this context, in particular, disciplinary proceedings against judges were mentioned regularly. Other issues raised by the responding courts included: the non-transparent allocation of cases by a classified algorithm, the excessive influence of the Minister of Justice on the functioning of courts through administrative supervision, as well as

\footnotetext{
${ }^{73}$ Celmer No. 5, supra note 53, para. 3; High Court (letter of 8 August 2018); Juzgado Central de Instrucción (letter of 24 September 2018).

${ }^{74}$ Rechtbank Amsterdam (Decision of 4 October 2018), ECLI:NL:RBAMS:2018:7032, para. 4.4.3; Oberlandesgericht Karlsruhe (Decision of 31 October 2018), Ausl 301 AR 95/18, paras. 21-33.

${ }^{75}$ High Court (Judgment of 1 August 2018), The Minister for Justice and Equality v. Artur Celmer (No. 4), [2018] IEHC 484, paras. 37, 40-41, 47.

${ }^{76}$ Regional Court in Warsaw (Letter of 26 September 2018). http://bip.warszawa.so.gov.pl/ attachments/download/7511. Accessed 20 July 2019, p. 9.
} 
the premature, arbitrary dismissal and appointment of (vice-)presidents of courts or the politicised composition of the National Council of the Judiciary. In turn, some replies were limited to expressing views in line with the official stance of the government (e.g. 'the National Council of the Judiciary is the independent body responsible for guaranteeing [judge's] rights '). ${ }^{77}$ or individual, hopeful opinions of the responding judge ('I would like to express my conviction that the majority of judges in the Republic of Poland stand up for their independence $).^{78}$

Some of the answers were laconic or evasive and, in the opinion of the requesting court, contributed very little to the understanding of the general situation in Poland. ${ }^{79}$ Some courts invoked the lack of a formal competence to provide answers in the required material scope (e.g. concerning the general situation of the rule of law in Poland, disciplinary proceedings against judges, the dismissal of presidents and vice-presidents of ordinary courts, the use of the extraordinary appeal, the evaluation of politicians' statements, the position of the Minister of Justice towards statements of his deputy etc.) or the lack of knowledge (e.g. about the disciplinary proceedings, the employment of assessors or judges' assistants, the extraordinary appeal, the statements of the deputy minister etc.). Sometimes both the lack of competence and the lack of knowledge were invoked simultaneously. In situations where the court is not capable of responding to some questions raised by the executing authority, it should perhaps approach the authority (or person) that has such knowledge or competence rather than ignore the questions or leave them unanswered. Excessive brevity or the lack of answer may make the requesting authority repeat or reformulate the questions, which will generate unnecessary additional communication and negatively affect the length of the proceedings. In ten very similar decisions of early 2019, the court in Amsterdam held that the answers of the Polish courts were insufficient to decide on the surrender of the persons wanted, and resolved to continue the dialogue. ${ }^{80}$ This mainly consisted in urging the requested court to provide or supplement the answers to the previously transmitted questions. ${ }^{81}$

Over time, the judicial dialogue began to involve other bodies in Poland, apart from the regional courts (sady okregowe), as the ones entitled to issue European arrest warrants. The communication also included district courts (sqdy rejonowe, e.g. in questions about assessors), courts of appeal, the Supreme Court (e.g. with

\footnotetext{
${ }^{77}$ Regional Court in Świdnica (Letter of 8 October 2010), p. 2.

${ }^{78}$ Regional Court in Rzeszów (Letter of 8 October 2010), p. 5.

${ }^{79}$ Celmer No. 5, supra note 53, para. 90.

${ }^{80}$ Rechtbank Amsterdam (Decisions of 4 January 2019), ECLI:NL:RBAMS:2019:33, 2019:42-2019:44, 2019:46-2019:51.

${ }^{81}$ In some cases, the second round of Polish courts' replies also left the EAW executing court unsatisfied; in a series of decisions it requested once again that the replies be supplemented; see Rechtbank Amsterdam (Decisions of 16 April 2019), ECLI:NL:RBAMS:2019:2750, 2019:2760, 2019:2792, 2019:2793, 2019:2801.
} 
regard to extraordinary appeals) and the disciplinary bodies (e.g. the scope of disciplinary proceedings with regard to individual judges). ${ }^{82}$

In April 2019, in some cases, after a second round of dialogue, the court of Amsterdam decided to surrender the persons requested. Similarly to the Irish court, the Rechtbank Amsterdam acknowledged the general concerns in respect of the impact of the changes in Poland on the rule of law as well as the concerns with regard to the right to a fair trial before the courts in which the transferred person will be tried. $^{83}$ That means that, again, two out of three tests were met. It considered, however, that the risk of breaching the right of the individual person to a fair trial was not demonstrated. It held that neither the personal circumstances of the suspect nor the nature of the offences for which he would be tried justifies a negative decision. The court concluded that the charges related to common criminal offences, so the suspect as well as the type of offences were not in any way in the special attention of the ruling politicians in Poland so as to give rise to inappropriate influence on the judges. ${ }^{84}$

\section{Evaluation of the CJEU Mechanism for the Assessment of Judicial Independence}

\subsection{Nemo Iudex in Causa Sua}

In the Aranyosi and Căldăraru cases, the answers to be given by national courts within the judicial dialogue mechanism were intended to refer to the conditions under which a custodial sentence was to be served. Thus they related to the area for which a separate branch of public administration was responsible: the prison authorities that remain outside the judiciary. In contrast, in the $L M$ case while it concerned a fair trial and judicial independence, national courts were requested to comment on themselves. A domestic judicial authority may be asked to assess particular courts of its own country (the ones having jurisdiction to try the case of the person being prosecuted) or the judiciary in general. Ergo, the court is being asked about a branch of the state structure of which it forms a part, within which it is established. This

\footnotetext{
${ }^{82}$ The survey of correspondence between courts shows that, occasionally, the understanding (translation) of the correspondence between courts could be a problem. Misunderstandings concerned some issues of importance, e.g.: which court will have jurisdiction to rule on the transferred person's case? Which court is actually giving the answer? (district or regional); Were the individual courts' presidents dismissed or they left due to the expiry of their term of office? Does the question relate to assessors or court assistants?

${ }^{83}$ See e.g. Rechtbank Amsterdam (Judgments of 16 April 2019), ECLI:NL:RBAMS:2019:2722, para. 5.4.1; 2019:2751, para. 5.4.1; 2019:2794, para. 6.4.2; 2019:2795, para. 4.4.1; 2019:2799, para. 4.4.1.

${ }^{84}$ ECLI:NL:RBAMS:2019:2722, supra note 85, para. 5.4.2; 2019:2751, para. 5.4.2; 2019:2794, para. 6.4.3; 2019:2795, para. 4.4.2; 2019:2799, para. 4.4.2.
} 
gives rise to potential conflicts unknown to the previously examined cases relating to prison conditions. ${ }^{85}$ In this context some difficult questions arise. Will such information meet the standard set by the Court of Justice? Will such information be objective and adequate? Will the assessment be fully reliable? Does a judge (court) who does not recognise any threats to the independence of the judiciary, contrary to the widely expressed and well-documented concerns, remain fully independent? How about a judge whose answers comply with to the expectations of political decision-makers, bearing in mind that their voice could have an impact on the judge's career? Would a judge admit receiving explicit or implicit instructions, suggestions or perhaps 'friendly advice' from the executive or other political actors? Answers to these questions can be challenging. On the other hand, how about a judge who provides critical comments on fair trial guarantees? Could he be afraid of condemnation, intimidation, legal harassment or threats of disciplinary proceedings on account of the answers he has given? These are legitimate concerns.

\subsection{Who Shall Answer?}

It is not clear who should answer the questions raised by the executing authority: the judge issuing the arrest warrant, the head of the court's department or the president of the court. The $L M$ ruling indicates, in general, that the issuing judicial authority should be addressed. The EAW Framework Decision only in general specifies as the addressee of the questions: the court issuing the EAW. It may seem a minor issue, yet in practice, the actual respondent may be of crucial significance to the content of the answers. It actually did happen that competing answers were provided to the same questions by different judges of the same court: the court's president and the judge who issued the warrant. ${ }^{86}$ An additional issue in the specific perspective of the $L M$ case was that the warrants to surrender the person were issued by three different Polish courts. The cooperation of the executing court with several issuing authorities, with regard to a single wanted person, may lead the former court to ambiguous conclusions.

In practice, questions from a foreign court are generally answered either by court presidents or heads of court departments or sometimes individual judges indicated by them. Occasionally, questions from the foreign court have been answered by the individual judges who actually issued the arrest warrant; this happened when expressly requested by the court executing the EAW. A review of the current practice of judicial dialogue suggests that when answers are given by court presidents or heads of departments, they are more often abbreviated and kept to a minimum. Their actual usefulness for the executing authority may therefore be limited. On the other hand, in the rare cases where answers are given by the

\footnotetext{
${ }^{85}$ See also i.a. Pech and Wachowiec (2019).

${ }^{86}$ For details see Filipek (2019), p. 29.
} 
individual judge who issued the warrant, these are usually more comprehensive, straightforward, and critical. It should be kept in mind that a number of courts' presidents were appointed by the Minister of Justice during a six-month period, when he enjoyed a fully discretionary power to replace presidents and vicepresidents of courts, or who were appointed by him following the expiry of their predecessor's term of office. The Minister, who is responsible for the changes in the Polish judiciary, is inclined to appoint persons who share his point of view.

\subsection{Material Scope of Judicial Dialogue}

Further concerns arise with regard to the scope of the questions asked by the judicial authorities executing arrest warrants and the stage at which the Q\&A mechanism should be employed. ${ }^{87}$ Could these be general questions, which concern systemic issues and therefore serve to perform a general assessment, the first stage of the tests pointed to by the Court of Justice? Or should these questions relate to the individualised courts which are competent to deal with the case of the person prosecuted after his transfer to the requesting country? Or, should they perhaps be limited mostly to the specific case and the person being prosecuted, and therefore serve the purpose of the ultimate individualised risk assessment?

The executing authority may indeed like to obtain information from the issuing court concerning a general or systemic situation in the Member State. This may be the case in particular with regard to the updating of existing information and cover recent legislative amendments, the development of case law or the administrative practice or any incidents that may be relevant to the assessment of threats to judicial independence. However, this possibility should be considered an exception. The executing authority should not make an initial effort to find and verify information simply by addressing, in the first place, the issuing judicial authority. The assessment of the fair trial guarantees and judicial independence by the executing court is also intended to apply to the responding court. The responding body is therefore in a difficult situation, as it speaks pro domo suo.

The judicial dialogue indicated by the Court of Justice should primarily serve the purpose of an individualised test carried out by the court executing the warrant, in which it assesses whether the particular person to whom the warrant refers, will be at risk of a breach of the right to a fair trial. A review of the existing practice indicates, however, that the executing courts do not refrain from asking general questions. ${ }^{88}$ In

\footnotetext{
${ }^{87}$ Doubts about the absence of a more precise indication by the CJEU of what the supplementary information should concern were already raised after the Aranyosi and Căldăraru judgment, see i.a. Kamiński (2019), p. 59.

${ }^{88}$ It would be advisable for judicial authorities from other Member States to use for the first and second stage of the $L M$ test, the available, general and up-to-date information from reliable sources, instead of referring to the Polish courts in the first place. Such sources include reports, analyses, opinions or recommendations from the international expert bodies: the Venice Commission, the UN
} 
fact, they are much more frequent than questions about the person prosecuted and his individual case. Nonetheless, there are also such courts, e.g. the London Court, according to which the requests for further information are appropriate only in relation to particular circumstances affecting the person requested by the EAW. ${ }^{89}$

\section{Final Remarks}

The mechanism of horizontal judicial dialogue between executing and issuing authorities has some potential to permit the gathering and verification of information on the Member State which issued the EAW, and to clarify doubts related to fair trial guarantees in that State. However, it is a deficient instrument which is not fully capable of examining judicial independence and threats to the rule of law. Its functioning so far raises a number of issues: is it mandatory or optional? What should be its material scope? Who should respond to the questions of the foreign court? Is it appropriate and credible to ask the judge to evaluate his own independence and the attitude of fellow judges?

The above considerations illustrate inherent limitations and substantial inadequacy of the model of supplementary questions to assess judicial independence and decide on the execution of the EAW in relation to fair trial standards. This mechanism assumes that judicial authorities will carry out a self-assessment of their independence and share it with foreign authorities. The adequacy and credibility of such an exercise may be disputed. Despite detailed guidance from the Court (or perhaps: due to them), such a procedure does not seem to be able to lead to a satisfactory result in many or perhaps in most cases.

In view of emerging difficulties, a question may arise whether it would not be a better idea to stick exclusively to the general test: i.e. the examination of the systemic risk of breach of independence of the courts following the formula set in the context of asylum law in the judgment in Case C-411/10 and C-493/10 N.S. ${ }^{90}$ This could lead to a quasi-automatic refusal to execute arrest warrants issued by Polish courts, and de facto result in the full exclusion of Poland's participation in the EAW mechanism. Such a solution would be questionable though. Its consequences could prove too far-reaching and hard to accept as it would not allow a more nuanced response to different specific circumstances of EAW cases.

In Poland's current situation, a general exclusion of all courts from judicial cooperation within the EU would result in a vote of no confidence against the

\footnotetext{
Special Rapporteur on the independence of judges and lawyers; the judges' associations: 'Iustitita', 'Themis'; or the civil society organisations: the Helsinki Foundation, the Batory Foundation, etc.

${ }^{89}$ London High Court of Justice (Judgment of 31 October 2018), Pawel Lis and others, [2018] EWHC 2848, postscript.

${ }^{90} \mathrm{CJEU}$, Case C-411/10 and C-493/10, N.S. v. Secretary of State for the Home Department and M. E. and Others, ECLI:EU:C:2011:865. See also i.a. von Bogdandy (2018), Frąckowiak-Adamska (2018a), Pech and Wachowiec (2019).
} 
entirety of the Polish judiciary. However, a prevailing majority of the total of more than 10,000 judges maintain their independence in difficult conditions, both legal and psychological, which they face in their daily work.

Another observation comes to mind relating to the extensive reach of the Court's arguments going beyond the framework of the case presented by the Irish Court, but being of relevance for the scope of judicial cooperation. The independence of national courts is also required when they refer questions for a preliminary ruling. Such a position was emphasized by the CJEU in its judgment in the Associação Sindical case, ${ }^{91}$ and repeated in the $L M$ judgment discussed here (para. 54). It means that in the case of each reference for a preliminary ruling from Poland (or from another Member State in which there are corresponding doubts as to the respect of the fundamental right to a fair trial) it will be necessary for the Court of Justice to begin with a full test of independence of the referring court in the manner specified in the $L M$ case. Did the Court in Luxembourg realise that its judgment might have such consequences?

In the context of a new category of questions referred for a preliminary ruling to the Court of Justice, in which national courts ask for an evaluation of their own independence, we may be soon witnessing new developments. Such questions have recently been referred to the CJEU by the courts in Germany (Verwaltungsgericht Wiesbaden) ${ }^{92}$ and Hungary (Central District Court in Pest) ${ }^{93}$ A new element is that the CJEU's reply and its appraisal is to apply to the very courts submitting the questions on judicial independence. This situation poses new challenges. First, if the Court of Justice were to answer the questions in the negative, i.e. if it considered that there is, indeed, a lack of a proper standard of judicial independence in the cases referred, the national court would then in fact not be entitled to ask a question for a preliminary ruling at all. In such cases, the answer on the substance of the question simultaneously becomes the answer on its admissibility. Would the Court of Justice therefore make an exception and admit the question on judicial independence from a non-independent court?, or would it rather declare the question inadmissible, yet pointing to the lack of independence of the requesting court?

Secondly, would the CJEU evaluate the independence of those courts by adapting the $L M$ test? Not likely. In both cases of the German and Hungarian courts, the questions were asked in the context of individual cases pending before the national court. However, the questions referred to Luxembourg did not directly concern the private party's right to a fair trial, that is, the individual fundamental right. Instead, they dealt with a more general, constitutional issue: the independence of the court. The latter does not have to be linked to the specific case of a particular person. In

\footnotetext{
${ }^{91} \mathrm{CJEU}$, Associação Sindical, supra note 4, para. 43.

${ }^{92}$ CJEU, Case C-272/19, Land Hessen. The Wiesbaden Court's self-evaluation of its independence from the viewpoint of EU standards was negative: 'Nach alledem dürfte das vorlegende Gericht die europarechtlichen Vorgaben nach Art. 47 Abs. 2 GrCH eines unabhängigen und unparteiischen Gerichts nicht in diesem Sinne erfüllen.', Verwaltungsgericht Wiesbaden (Decision of 28 March 2019), 6 K 1016/15. https://openjur.de/u/2169849.html. Accessed 20 July 2019.

${ }^{93}$ Biró (2019) and Szabó (2019).
} 
principle, therefore, there would be no need for a final (third) $L M$ test: the individual assessment of the specific case and the risks related to the party of the national proceeding. The Court of Justice could make a ruling after carrying out: (1) the general assessment of the existence of systemic or generalised deficiencies in the Member State's judiciary, and (2) the impact of these deficiencies on the particular courts, namely those which submitted the questions.

If such a scenario were to materialise, it could also be followed by the courts of the Member States deciding on the execution of the EAW. They could start asking questions not just about the protection of the individual's right of the requested person to a fair trial, but at a more general level about the independence of the court that is supposed to hear the case, after the person were transferred. Such an approach would safeguard the individual right to a fair trial while guaranteeing the independence of national courts and protecting the rule of law more effectively than in the $L M$ ruling.

\section{References}

Anagnostaras G (2016) Mutual confidence is not blind trust! Fundamental rights protection and the execution of the European arrest warrant: Aranyosi and Căldăraru. Common Mark Law Rev 6:1675-1704

Barcz J (2019) Unia Europejska wobec niepraworządnego państwa członkowskiego. Państwo i Prawo 1:3-23

Bárd P, van Ballegooij W (2018a) Judicial independence as a precondition for mutual trust. Verfassungsblog. https://doi.org/10.17176/20180410-104826

Bárd P, van Ballegooij W (2018b) The AG opinion in the Celmer case: why lack of judicial independence should have been framed as a rule of law issue. Verfassungsblog. https://doi.org/ 10.17176/20180702-173606-0

Biernat S (2018) How to assess the independence of Member State Courts? Verfassungsblog. https://doi.org/10.17176/20180730-100627-0

Biró M (2019) Hungarian judge requests European Court of Justice to examine his own independence. Index.hu. index.hu/english/2019/07/17/hungary_judicial_independence_european_ court_of_justice_suspended_case. Accessed 20 July 2019

Bogdanowicz P, Taborowski M (2018a) Brak niezależności sądów krajowych jako uchybienie zobowiązaniu w rozumieniu art. 258 TFUE (cz. I). Europejski Przegląd Sądowy 1:4-11

Bogdanowicz P, Taborowski M (2018b) Wyrok Trybunału Sprawiedliwości w sprawie 'Celmer'. Analiza w 10 punktach. https://archiwumosiatynskiego.pl/wpis-w-debacie/wyrok-trybunalusprawiedliwosci-w-sprawie-celmer-analiza-w-10-punktach. Accessed 20 July 2019

Dashwood A, Dougan M, Rodger B, Spaventa E, Wyatt D (2011) Wyatt and Dashwood's European Union law, 6th edn. Hart, Oxford

Filipek P (2018) Challenges to the rule of law in the European Union: the distressing case of Poland. Revista do Instituto Brasileiro de Direitos Humanos 17(18):221-248

Filipek P (2019) Rozproszona europejska kontrola przestrzegania prawa do rzetelnego procesu sądowego w świetle zasady wzajemnego zaufania i wyroku C-216/18 PPU, LM. Europejski Przegląd Sądowy 2:14-31

Frąckowiak-Adamska A (2018a) Drawing red lines with no (significant) bite - why an individual test is not appropriate in the LM case. Verfassungsblog. https://doi.org/10.17176/20180730104735-0 
Frąckowiak-Adamska A (2018b) Następstwa wyroku w sprawie LM (Celmer) i postępowania na podstawie art. 7 TUE dla funkcjonowania sądów polskich w ramach wspólnoty prawnej UE. In: Barcz J, Zawidzka-Łojek A (eds) Sądowe mechanizmy ochrony praworządności w Polsce w świetle najnowszego orzecznictwa Trybunału Sprawiedliwości UE. Warszawa, pp 89-105

Górski M (2016) Prawo do skutecznego środka prawnego w art. 47 Karty Praw Podstawowych UE - znaczenie i deficyty. Europejski Przegląd Sądowy 8:37-44

Grabowska-Moroz B (2018a) Co orzekł Trybunał Sprawiedliwości w sprawie Celmer? https:// archiwumosiatynskiego.pl/wpis-w-debacie/co-orzekl-trybunal-sprawiedliwosci-w-sprawiecelmer. Accessed 20 July 2019

Grabowska-Moroz B (2018b) Zaufanie bez wzajemności - czyli europejski nakaz aresztowania w czasach kryzysu praworządności. Refleksje na kanwie sprawy Celmer. Kwartalnik o Prawach Człowieka 1-2:16-26

Grabowska-Moroz B (2019) Sądowa kontrola Trybunału Sprawiedliwości UE w zakresie zmian dotyczących niezależności sądownictwa w państwie członkowskim UE - uwagi na tle Polski i Węgier. In: Bojarski Ł et al (eds) Konstytucja. Praworządność. Władza sądownicza. Aktualne problemy trzeciej władzy w Polsce, Warszawa, pp 403-430

Grzelak A (2018) Wzajemne zaufanie jako podstawa współpracy sądów państw członkowskich UE w sprawach karnych (uwagi na marginesie odesłania prejudycjalnego w sprawie C-216/18 PPU Celmer). Państwo i Prawo 10:50-66

Grzeszczak R, Krajewski M (2014) 'Sąd' w świetle przepisów art. 47 KPP oraz art. 267 TFUE. Europejski Przegląd Sądowy 6:4-14

Hofmański P, Wróbel A (2010) Komentarz do art. 6 EKPC. In: Garlicki L (ed) Konwencja o Ochronie Praw Człowieka i Podstawowych Wolności. Tom I. Komentarz do artykułów 1-18. Warszawa, pp 241-461

Kamiński IC (2019) Unijna zasada praworządności (państwa prawa) i uprawnienia sądów. In: Bojarski Ł et al (eds) Konstytucja. Praworządność. Władza sądownicza. Aktualne problemy trzeciej władzy w Polsce, Warszawa, pp 35-64

Krajewski M (2018) Who is afraid of the European Council? The Court of Justice's Cautious approach to the independence of domestic judges. Eur Const Law Rev 4:792-813

Kuijer M (2018) The rule of law in crisis? - some observations from the perspective of the Venice commission. Osteuropa Recht 4:530-551

Lawson R (2018) Protecting the independence of the judiciary: possibilities and limits of the European Convention on Human Rights. Revista do Instituto Brasileiro de Direitos Humanos 17(18):249-264

Lenaerts K (2017) La vie après l'avis: exploring the principle of mutual (yet not blind) trust. Common Mark Law Rev 3:805-840

Lenaerts K (2018) The Court of Justice and national courts: a dialogue based on mutual trust and judicial independence. http://www.nsa.gov.pl/download.php?id=753. Accessed 20 July 2019

Lenaerts K, Maselis I, Gutman K (2014) EU procedural law. Oxford University Press, Oxford

Łętowska E (2018) Convulsions in the rule of law. Osteuropa Recht 4:607-623

Lewandowski W (2019) Pomiędzy Scyllą zawieszenia wzajemnego zaufania i Charybdą fragmentaryzacji standardu ochrony prawa podstawowego - dylematy Trybunału Sprawiedliwości w wyroku C-216/18 PPU, LM. Europejski Przegląd Sądowy 2:4-13

Nita-Światłowska B (2018) Europejski nakaz aresztowania - ograniczona zasada wzajemnego zaufania. Kwartalnik o Prawach Człowieka 1-2:5-16

Pech L (2014) Commentary to Art. 47. In: Peers S et al (eds) The EU Charter of fundamental rights. A commentary. Hart, Oxford

Pech L, Platon S (2018) Judicial independence under threat: the Court of Justice to the rescue in the ASJP case. Common Mark Law Rev 6:1827-1854

Pech L, Wachowiec P (2019) 1095 Days later: from bad to worse regarding the rule of law in Poland (Part II). Verfassungsblog. https://doi.org/10.17176/20190211-221846-0

Sadurski W (2018) Anti-constitutional transformation in Poland: dimensions, sources, and prospects. Osteuropa Recht 4:624-636 
Sadurski W (2019) Poland's constitutional breakdown. Oxford University Press, Oxford

Safjan M (2018) Domestic infringements of the rule of law as a European Union problem. Osteuropa Recht 4:552-560

Safjan M (2019) Rządy prawa a przyszłość Europy. Europejski Przegląd Sądowy 8:4-11

Scheppele KL (2018) Rule of law retail and rule of law wholesale: the ECJ's (Alarming) 'Celmer' decision. Verfassungsblog. https://doi.org/10.17176/20180730-095958-0

Schütze R (2018) European Union law, 2nd edn. Cambridge University Press, Cambridge

Schwarze J (2012) Kommentar zu Art. 267. In: Schwarze J (ed) EU-Kommentar, 3rd edn. Nomos, Baden-Baden

Sillen J (2019) The concept of 'internal judicial independence' in the case law of the European Court of Human Rights. Eur Const Law Rev 1:104-133

Szabó DG (2019) A Hungarian Judge Seeks Protection from the CJEU - Part I. Verfassungsblog. https://verfassungsblog.de/a-hungarian-judge-seeks-protection-from-the-cjeu-part-i. Accessed 20 July 2019

Taborowski M (2018) Naruszenie elementów zasady państwa prawa (art. 2 TUE) jako ograniczenie zasady wzajemnego zaufania w prawie Unii Europejskiej (w świetle wyroku LM (Celmer). In: Barcz J, Zawidzka-Łojek A (eds) Sądowe mechanizmy ochrony praworządności w Polsce w świetle najnowszego orzecznictwa Trybunału Sprawiedliwości UE, Warszawa, pp 73-88

Taborowski M (2019) Mechanizmy ochrony praworządności państw członkowskich w prawie Unii Europejskiej. Studium przebudzenia systemu ponadnarodowego, Warszawa

von Bogdandy A et al (2018) Drawing red lines and giving (some) bite - the CJEU's deficiencies Judgment on the European rule of law. Verfassungsblog. https://doi.org/10.17176/20180730102416-0

Wachowiec P (2019) Pojęcie na gruncie traktatów unijnych. Polski wkład do redefinicji? In: Bojarski $€$ et al (eds) Konstytucja. Praworządność. Władza sądownicza. Aktualne problemy trzeciej władzy w Polsce, Warszawa, pp 565-579

Wyrzykowski M (2017) 'Wrogie przejęcie' porządku konstytucyjnego. In: Bernatt M et al (eds) Wyzwania dla ochrony konkurencji i regulacji rynku, Warszawa, pp 831-853

Xanthopoulou E (2018) Mutual trust and rights in EU criminal and asylum law: three phases of evolution and the uncharted territory beyond blind trust. Common Mark Law Rev 2:489-510

Stanisław Biernat is a Professor of European law at the Jagiellonian University, Krakow.

Pawet Filipek is an Associate Professor at the University of Economics, Krakow.

Open Access This chapter is licensed under the terms of the Creative Commons Attribution 4.0 International License (http://creativecommons.org/licenses/by/4.0/), which permits use, sharing, adaptation, distribution and reproduction in any medium or format, as long as you give appropriate credit to the original author(s) and the source, provide a link to the Creative Commons license and indicate if changes were made.

The images or other third party material in this chapter are included in the chapter's Creative Commons license, unless indicated otherwise in a credit line to the material. If material is not included in the chapter's Creative Commons license and your intended use is not permitted by statutory regulation or exceeds the permitted use, you will need to obtain permission directly from the copyright holder.

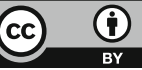

